\title{
Effects of Heat Treatment on Mechanical Properties and Corrosion Fatigue Strength in Physiological Saline Solution of New Titanium Alloys for Medical Implants
}

\author{
Yoshimitsu Okazaki, Yoshimasa Ito* and Tetsuya Tateishi** \\ Mechanical Engineering Laboratory, Agency of Industrial Science and Technology, Ministry of \\ International Trade and Industry, 1-2 Namiki, Tsukuba 305, Japan \\ * Technical Development Group Kobe Steel, Ltd, Wakinohamacho, Kobe 651, Japan \\ ** National Institute for Advanced Interdisciplinary Research, 1-1 Higashi, Tsukuba 305, Japan
}

\begin{abstract}
Ti-15mass $\% \mathrm{Zr}-4 \% \mathrm{Nb}-4 \% \mathrm{Ta}-0.2 \% \mathrm{Pd}$ and $\mathrm{Ti}-15 \% \mathrm{Sn}-4 \% \mathrm{Nb}-2 \% \mathrm{Ta}-0.2 \% \mathrm{Pd}$ alloys not containing $\mathrm{V}$ and $\mathrm{Al}$ for surgical implantation were cast by plasma electron beam melting. The effect of heat treatment on room temperature strength and corrosion fatigue strength were investigated by aging treatment after solution trea tment. The alloys were forged in their $\alpha$ and $\alpha+\beta$ regions, and then solution-treated at $953 \sim 1173 \mathrm{~K}$ for $3.6 \mathrm{ks}$. Optimized solution treatment conditions are $1038 \mathrm{~K}-3.6 \mathrm{ks}$ for Ti-Zr alloy and $1098 \mathrm{~K}-3.6 \mathrm{ks}$ for Ti-Sn alloy containing $15 \sim 20$ vol\% of primary $\alpha$ phase. After solution treatment under the optimized conditions, aging treatment was carried out at $623 \sim 873 \mathrm{~K}$ for $600 \mathrm{~s} \sim 108 \mathrm{ks}$. Optimized aging conditions for Ti- $\mathrm{Zr}$ and Ti-Sn alloys were at $673 \mathrm{~K}$ for $36 \mathrm{ks}$ and at $723 \mathrm{~K}$ for $36 \mathrm{ks}$, respectively. The room temperature strengths of these solution treated and aged alloys were about $30 \%$ higher than the annealed alloys. It is revealed by transmission electron microscopic observation that, fine $\alpha$ phase precipitates in $\alpha$ 'martensitic matrix are responsible for the age hardening. The corrosion fatigue test in a physiological saline solution was carried out under the condition of a tension to tension mode with a sine wave at a stress ratio of 0.1 , at a frequency of $10 \mathrm{~Hz}$ in Eagle's $\mathrm{MEM}+\mathrm{fetal}$ bovine serum solution using an environment cell with $90 \% \mathrm{~N}_{2}+5 \% \mathrm{CO}_{2}+5 \% \mathrm{O}_{2}$ gas bubbling at $310 \mathrm{~K}$. The fatigue strength at $10^{7}$ cycles in solution-treated and aged Ti- $15 \% \mathrm{Zr}-4 \% \mathrm{Nb}-4 \% \mathrm{Ta}-0.2 \% \mathrm{Pd}$ and Ti- $15 \% \mathrm{Sn}-4 \% \mathrm{Nb}-2 \%$ Ta-0.2\% Pd alloys were about $650 \mathrm{MPa}$ and $800 \mathrm{MPa}$ respectively, which were about $20 \sim 30 \%$ higher than those of the annealed alloys.
\end{abstract}

Keywords : titanium alloy, medical implant, microstructure, Vickers hardness, mechanical properties, corrosion fatigue strength, physiological saline solution, effect of heat treatment

\section{I . Introduction}

Stainless steel (SUS 316L), Co-Cr alloy, pure titanium and titanium alloys are being used as standard surgical implant materials. Among them Ti-6\%Al-4\%V ELI alloy is being viewed with keen interest, which originally had been used in aerospace applications. The cytotoxicity of pure metals and surgical implant materials have been reported by Steinemann ${ }^{(1)}$. The high cytotoxicity of $\mathrm{V}$ and tissue response of capsule (scar tissue) type due to $\mathrm{Al}$ have been demonstrated, while $\mathrm{Zr}, \mathrm{Ti}, \mathrm{Nb}$, Ta and $\mathrm{Pt}$ exhibited excellent biocompatibility and belong to loose connective vascularised (vital) group in the type of the tissue reaction. Also it is reported that the rate of colony formation (\%) =(number of colonies in each concentration / number of control colonies) $\times 100$ of V79 cells originating from the lung fibroblast in a Chinese hamster decreases linearly from $\mathrm{V}$ ion concentration of 0.16 mass ppm, and no colony is formed in a medium solution containing 1.1 mass ppm of
$\mathrm{V}$ ion ${ }^{(2)}$. As $\alpha+\beta$ type alloys for medical implants not containing $\mathrm{V}$, alloys such as $\mathrm{Ti}-6 \% \mathrm{Al}-7 \% \mathrm{Nb}$, Ti-5\% Al2.5\%Fe, Ti-6\%Al-6\%Nb-1\%Ta, Ti-5\%Al-3\%Mo-4\%Zr, Ti-6\%Al-2\%Nb-1\%Ta have been developed. As $\beta$ type alloys, Ti-11.5\%Mo-6\% Zr-2\%Fe alloy and Ti-15\%Mo$5 \% \mathrm{Zr}-3 \% \mathrm{Al}^{(3)(4)}, \mathrm{Ti}-15 \% \mathrm{Mo}-3 \% \mathrm{Nb}-3 \% \mathrm{Al}-0.2 \% \mathrm{Si}$, Ti-15\% Mo-3\%Nb-3\%Al-0.3\%O, Ti-11\%Mo-6\%Zr-4.5\%Sn and Ti $-13 \% \mathrm{Nb}-13 \% \mathrm{Zr}$ alloys ${ }^{(5)}$ have been developed for medical implant. A causal relationship between $\mathrm{Al}$ and the occurrence of senile dementia of Alzheimer type has been suggested by many researchers ${ }^{(6)-(12)}$. Moosmann et. al. reported that the concentration of alloying elements released from $\mathrm{Ti}-6 \% \mathrm{Al}-4 \% \mathrm{~V}$ alloy to the peripheral tissues around the implant in the human body increases in the following order ; $\mathrm{Ti}>\mathrm{Al}>\mathrm{V}^{(13)}$. Agins et. al. confirmed the presence of $\mathrm{Ti}, \mathrm{Al}$, and $\mathrm{V}$ in the patients who were failed cases of surgical implantation of Ti-6Al-4V alloy in hip joint. The histologic reaction that produced polynuclear leukocytes and giant cells was noted, and plasmacytes were frequently 
observed if $\mathrm{Al}$ and $\mathrm{V}$ existed in large quantities in the tissue of the implanted part, causing the patient to present symptoms similar to allergic reaction and chronic inflammatory reaction ${ }^{(14)}$. Also, Kawahara reported that metallic Ti, Sn, Zr, Pd and Ta are low cytotoxic elements ${ }^{(15)}$. The toxicity of $\mathrm{Sn}$ and its compounds have been summarized by many researchers ${ }^{(16)-(18)}$ and it has been clarified that the toxicology of $\mathrm{Sn}$ is almost entirely the toxicity of organic compounds of Sn.

Thus, the pure metallic elements $\mathrm{Zr}, \mathrm{Nb}, \mathrm{Ta}, \mathrm{Pd}$ and Sn, which can be expected to improve mechanical properties, corrosion resistance and biocompatibility could be selected as biocompatible alloying elements. Ti- $15 \% \mathrm{Zr}-4 \% \mathrm{Nb}-4 \%$ Ta-0.2\%Pd and Ti-15\%Sn-4\%Nb-2\%Ta-0.2\%Pd alloys without $\mathrm{V}$ and $\mathrm{Al}$ are currently being developed by the authors to excel in corrosion resistance, strength and ductility, and also to ensure long-term safety of use in the body for a period of more than 20 years as medical implants ${ }^{(2)(4)(19)-(21)}$. In this research, the effect of heat treatment on the mechanical properties at room temperature and the corrosion fatigue strength in a physiological saline solution of these $\mathrm{Ti}$ alloys were investigated.

\section{Experimental method}

Ti-15\%Zr-4\%Nb-4\% Ta-0.2\%Pd (Ti-Zr) and Ti-15\%Sn-4\% $\mathrm{Nb}-2 \% \mathrm{Ta}-0.2 \% \mathrm{Pd}$ (Ti-Sn) alloys designed with biocompatible alloying elements were melted by plasma electron beam. About $5 \mathrm{~kg}$ ingots were homogenized at $1273 \sim 1373 \mathrm{~K}$ for $7.2 \mathrm{ks}$, and then, they were hot-forged into round bars of $17 \mathrm{~mm}$ in diameter by $\beta$ and $\alpha-\beta$ forgings. $\alpha-\beta$ forgings were carried out by reheating at $1123 \mathrm{~K}$. Specimens of $17 \mathrm{~mm}$ in diameter and $10 \mathrm{~mm}$ in thickness cut from the sample alloys were solution-treated in the temperature range of $953 \sim 1173 \mathrm{~K}$ for $3.6 \mathrm{ks}$ at intervals of $20 \mathrm{~K}$, and then they were water-quenched. Hot-rolled block specimens with a thickness of $5 \mathrm{~mm}$ were also solution-treated under the optimized solution treatment conditions which included $15 \sim 20 \mathrm{vol} \%$ of primary $\alpha$ phase content (1038 K for $3.6 \mathrm{ks}$ for Ti-Zr alloy, $1098 \mathrm{~K}$ for 3.6 $\mathrm{ks}$ for Ti-Sn alloy). The block specimens of $10 \times 10 \times 5$ $\mathrm{mm}$ were cut from the sample alloys, aged in the temperature range of $623 \sim 873 \mathrm{~K}$ for $0.6 \sim 108 \mathrm{ks}$ (10 $\min \sim 30 \mathrm{~h}$ ) at intervals of $50 \mathrm{~K}$, which were then air-cooled. For the purpose of comparison,specimens were also annealed at $973 \mathrm{~K}$ for $7.2 \mathrm{ks}$.
Moreover pure $\mathrm{Ti}$ grade 2 and $\mathrm{Ti}-6 \% \mathrm{Al}-4 \% \mathrm{~V}$ ELI alloy were melted by vacuum arc melting. After $\beta$ and $\alpha-\beta$ forging, the alloys were annealed for $7.2 \mathrm{ks}$ at $973 \mathrm{~K} . \quad \beta$ forging : $1373 \mathrm{~K}, \alpha-\beta$ forging : $1173 \mathrm{~K} \sim 1223 \mathrm{~K}$ (Ti$6 \% \mathrm{Al}-4 \% \mathrm{~V} \mathrm{ELI}$ ) and $1103 \mathrm{~K} \sim 1123 \mathrm{~K}$ (pure Ti grade 2 ). Table 1 shows the chemical composition of these materials.

After polishing with waterproof emery paper of \#120 \#4000 and buff-cleaning with OP-S suspension, Vickers hardness was measured. Also after polishing and buff-cleaning, the test specimens were etched in hydrofluoric nitrate solution containing $10 \% \mathrm{H}_{2} \mathrm{O}_{2}$ (HF: $\mathrm{HNO}_{3}: \mathrm{H}_{2} \mathrm{O}=15 \mathrm{~cm}^{3}: 20 \mathrm{~cm}^{3}: 65 \mathrm{~cm}^{3}$ ). The microstructure was observed by using an optical microscope, a scanning electron microscope (SEM) and a transmission electron microscope(TEM-2000EX), and the phases were identified with a X-ray diffractometer. The sample specimen for transmission electron microscope observation was prepared by electrolytic polishing ( $35 \mathrm{~V}, 50$ to $70 \mathrm{~mA})$ with $95 \%$ acetic anhydride $+5 \%$ perchloric acid solution. X-ray diffraction profiles were obtained using $\mathrm{Fe} \mathrm{K} \alpha$ X-ray at a tube voltage of $40 \mathrm{kV}$, tube current of $0.03 \mathrm{~A}$ and scanning rate $(2 \theta)$ of $1^{\circ} / \mathrm{min}$. Moreover, to examine the room temperature strengths of the alloys after annealing, solution treatment and aging treatment, tensile testings were conducted with test specimens, $6 \mathrm{~mm}$ in diameter and 22 $\mathrm{mm}$ in gage length with a crosshead speed of $8.33 \times 10^{-6}$ $\mathrm{m} / \mathrm{s}(0.5 \mathrm{~mm} / \mathrm{min})$.

The fatigue test specimen with dimension and shape as shown in Figure 1 was cut from the sample alloys. The corrosion fatigue test was carried out in a physiological saline solution containing $10 \%$ sodium bicarbonate solution $(20 \mathrm{ml})$ and fetal bovine serum $(5 \mathrm{ml})$ added to Eagle's MEM solution $\left(\mathrm{H}_{2} \mathrm{O}: 100 \mathrm{ml}\right.$, eagle's MEM:0.94 g). To remove the residual strain on the surface of alloy caused in the manufacturing process, the surface of the test specimen was fully ground with \#600 waterproof emery paper in the direction parallel to the test specimen. The test specimen was fitted inside a cell (polyethylene, inner diameter : $40 \mathrm{~mm}$, outer diameter : $50 \mathrm{~mm}$, height : 55 $\mathrm{mm}$ ) containing Eagle's MEM+fetal bovine serum solution and then the test specimen was set on a corrosion fatigue testing machine (Servopulsar; manufactured by Shimadzu Co.). The corrosion fatigue test was conducted by circulating hot water at about $42{ }^{\circ} \mathrm{C}$ around the cell containing the physiological saline solution so as to maintain $310 \mathrm{~K}\left(37{ }^{\circ} \mathrm{C}\right)$ inside the cell. To make the oxygen concentration in the saline solution closer to that of the living body, and to maintain $\mathrm{pH}$ value at 7.4 ,

Table 1 Chemical composition (mass\%) of materials used .

\begin{tabular}{l|c|c|c|c|c|c|c|c|c|c|c|c|c|c}
\hline \hline \multicolumn{1}{c|}{ Titanium alloy } & $\mathrm{Zr}$ & $\mathrm{Sn}$ & $\mathrm{Nb}$ & $\mathrm{Ta}$ & $\mathrm{Pd}$ & $\mathrm{Al}$ & $\mathrm{V}$ & $\mathrm{Mo}$ & $\mathrm{Fe}$ & $\mathrm{O}$ & $\mathrm{N}$ & $\mathrm{H}$ & $\mathrm{C}$ & $\mathrm{Ti}$ \\
\hline Pure Ti grade 2 & - & - & - & - & - & - & - & - & 0.062 & 0.078 & 0.0037 & 0.0012 & 0.007 & $\mathrm{Bal}$. \\
\hline $\mathrm{Ti}-6 \% \mathrm{Al}-4 \% \mathrm{~V} \mathrm{ELI}$ & - & - & - & - & - & 6.42 & 4.19 & - & 0.198 & 0.101 & - & 0.0052 & 0.011 & $\mathrm{Bal}$. \\
\hline $\begin{array}{l}\mathrm{Ti}-15 \% \mathrm{Zr}-4 \% \mathrm{Nb}-4 \% \mathrm{Ta} \\
-0.2 \% \mathrm{Pd}\end{array}$ & 15.1 & - & 3.97 & 3.86 & 0.18 & - & - & - & - & 0.096 & 0.0046 & 0.0013 & - & $\mathrm{Bal}$. \\
\hline $\begin{array}{l}\mathrm{Ti}-15 \% \mathrm{Sn}-4 \% \mathrm{Nb}-2 \% \mathrm{Ta} \\
-0.2 \% \mathrm{Pd}\end{array}$ & - & 14.74 & 4.12 & 2.02 & 0.18 & - & - & - & - & 0.054 & 0.0038 & 0.0011 & - & $\mathrm{Bal}$. \\
\hline
\end{tabular}


a small amount of $90 \% \mathrm{~N}_{2}+5 \% \mathrm{CO}_{2}+5 \% \mathrm{O}_{2}$ mixed gas was bubbled through the solution. As the corrosion test conditions, a sine wave having an $\mathrm{R}$ ratio (minimum tensile stress) $/$ (maximum tensile stress) of 0.1 , a frequency of $10 \mathrm{~Hz}$, and a number of cycles up to $10^{8}$ times were maintained.

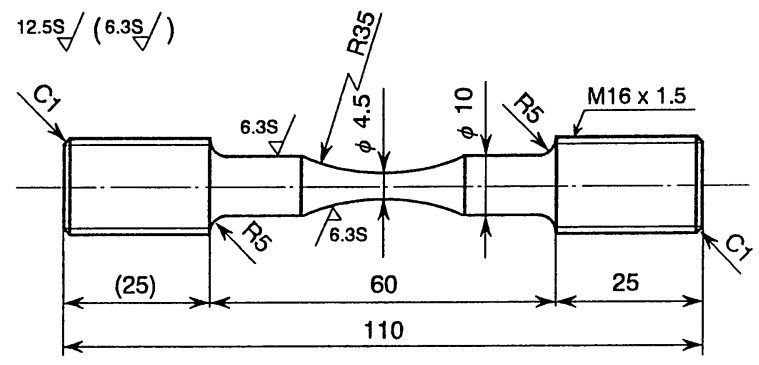

Fig.1 Dimensions of test specimen for corrosion fatigue.

\section{Results and Discussion}

\section{Vickers Hardness and Microstructure of Solution-treated Alloys}

Figure 2 shows the effect of solution treating temperature on Vickers hardness and microstructure. The Vickers hardness of Ti-Zr alloy increased linearly with increasing solution treating temperature up to 953 1033 K (680 760 ${ }^{\circ} \mathrm{C}$ ), but remained almost constant at temperatures greater than $1053 \mathrm{~K}\left(780^{\circ} \mathrm{C}\right)$. The Vickers hardness of Ti-Sn alloy showed a tendency to decrease with increasing solution treating temperature up to $953 \sim 1053 \mathrm{~K}\left(680 \sim 780{ }^{\circ} \mathrm{C}\right)$, but otherwise increased with increasing solution treating temperature in the temperature range of 1053 1113 $\mathrm{K}$ $\left(780 \sim 840^{\circ} \mathrm{C}\right)$, and thereafter remained nearly constant. At the solution treating temperature of $973 \mathrm{~K}$, Ti-Zr alloy showed a two-phase $(\alpha+\beta)$ microstructure, and the $\beta$ phase grew with increasing solution treating temperature, and at $1033 \mathrm{~K}\left(760^{\circ} \mathrm{C}\right)$, the $\alpha$ phase existed as islands in the $\beta$ phase matrix. The $\beta$ phase appears white in the SEM micrographs, but $X$-ray diffraction profiles indicated that it was almost transformed to $\alpha^{\prime}$ martensite by water quenching. The single $\beta$ phase maintained at $1053 \mathrm{~K}$ (780 ${ }^{\circ} \mathrm{C}$ ) was transformed to $\alpha^{\prime}$ martensite during water quenching. The Ti-Sn alloy showed a similar tendency, except that, the $\beta$ transition temperature was high. These observations were in conformation with the $\beta$ transus obtained by differential thermal analysis $(1055 \mathrm{~K}$ for Ti-Sn alloy, $1119 \mathrm{~K}$ for Ti-Sn alloy). However, the X-ray diffraction profiles of the Ti-Sn alloy indicated the peak of $\alpha$ " martensite.

In order to determine the optimum solution treating temperature, the volume fraction of primary $\alpha$ phase was examined. As shown in Figure 3, the volume fraction of primary $\alpha$ phase decreased markedly with increasing solution treating temperature in both $\mathrm{Ti}-\mathrm{Zr}$ and $\mathrm{Ti}-\mathrm{Sn}$ alloys. Optimized solution treatment conditions containing $15 \sim 25 \%$ volume fraction of primary $\alpha$ phase were selected at $1038 \mathrm{~K}\left(765^{\circ} \mathrm{C}\right)-3.6 \mathrm{ks}$ for Ti-Zr alloy and $1098 \mathrm{~K}(825$ $\left.{ }^{\circ} \mathrm{C}\right)-3.6 \mathrm{ks}$ for Ti-Sn alloy.

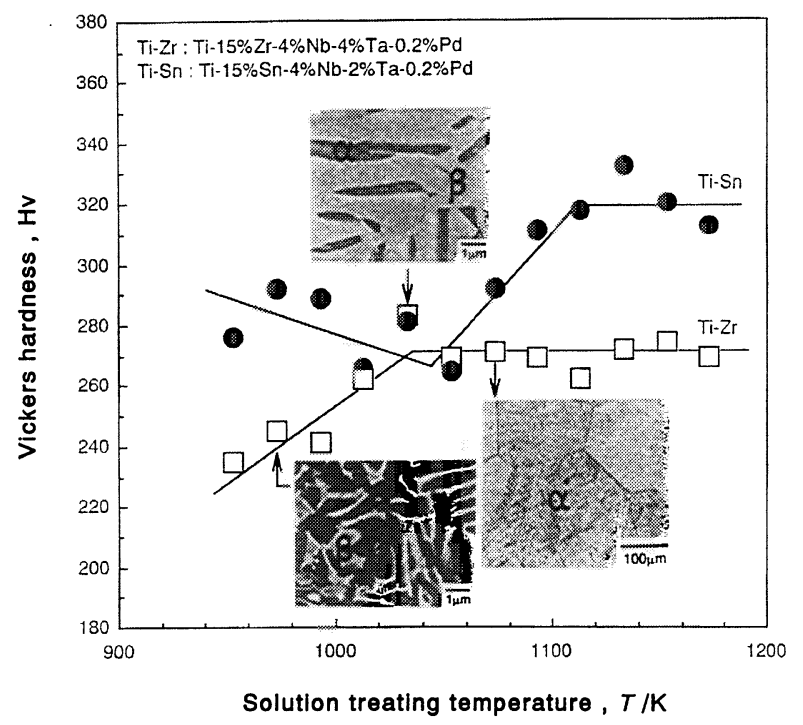

Fig.2 Effect of solution treating temperature on Vickers hardness and microstructure.

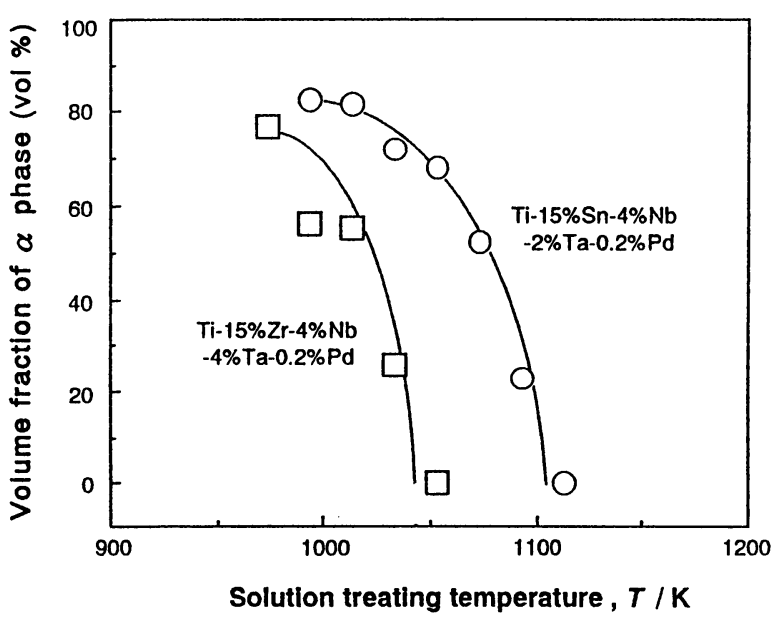

Fig.3 Change in volume fraction of primary $\alpha$ phase with solution treating temperature

\section{Hardness and Microstructure of Alloy Aged After Solution Treating}

Figure 4 shows the changes in Vickers hardness of $\mathrm{Ti}-\mathrm{Zr}$ and Ti-Sn alloys with aging temperature and aging time. The Vickers hardness of both alloys increased markedly for $0.6 \mathrm{ks}$ aging at $673 \mathrm{~K}$ and $723 \mathrm{~K}$. It was maximum after aging for $36 \mathrm{ks}$, then showed a gradual downward trend. Vickers hardness of $\mathrm{Ti}-\mathrm{Zr}$ alloy increased for $0.6 \mathrm{ks}$ aging at $773 \mathrm{~K}$, but declined with the increase of aging time, and went down to a value lower than that of the solution-treated alloy at temperatures above $823 \mathrm{~K}\left(550^{\circ} \mathrm{C}\right)$. The Ti-Sn alloy showed a similar tendency, with its Vickers hardness decreasing with increasing aging temperature. Figure 5 shows SEM micrographs of solution-treated and aged Ti-Sn alloy. In the case of the solution-treated alloy shown in Figure 5(a), the primary $\alpha$ phase and $\beta$ phase constitute the transformed $\alpha^{\prime}$ martensitic matrix. The solutiontreated alloy showed no change in the SEM micrographs even after aging at $723 \mathrm{~K}$ for $36 \mathrm{ks}$. 

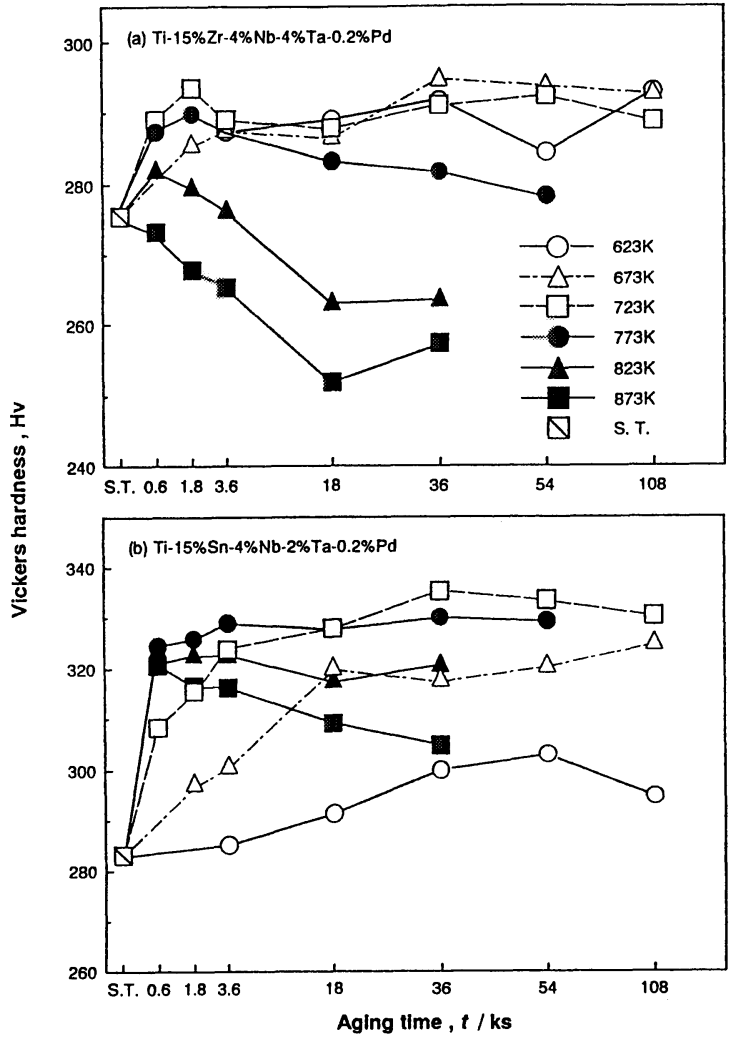

Fig.4 Change in Vickers hardness with aging temperature and aging time. (a): $\mathrm{Ti}-15 \% \mathrm{Zr}-4 \% \mathrm{Nb}-4 \% \mathrm{Ta}-0.2 \% \mathrm{Pd}$ alloy, (b): $\mathrm{Ti}-15 \% \mathrm{Sn}-4 \% \mathrm{Nb}-2 \% \mathrm{Ta}-0.2 \% \mathrm{Pd}$ alloy.

However, aging at $823 \mathrm{~K}\left(550^{\circ} \mathrm{C}\right)$ caused the $\beta$ phase precipitation in the primary $\alpha$ region, and $\beta$ phase precipitates observed in the matrix increased with increasing aging temperature. Figure 6 shows the X-ray diffraction profiles of solution-treated and aged Ti-Sn alloy. As seen in the figure, primary $\alpha$ and $\alpha$ " martensite as well as the peak of $\alpha^{\prime}$ martensite were observed for the solution-treated alloy, and this $\alpha$ " martensite peak disappeared when the alloy was aged at $723 \mathrm{~K}\left(450{ }^{\circ} \mathrm{C}\right)$ for $36 \mathrm{ks}$. As for the alloy aged at $873 \mathrm{~K}$ for $36 \mathrm{ks}$, the $\beta$ phase peak generated by aging was observed. Since a similar tendency was observed with $\mathrm{Ti}-\mathrm{Zr}$ alloy, it is considered that phase precipitation due to aging causes a decline in Vickers hardness. Optimized aging treatment conditions for securing the maximum hardness were determined at $673 \mathrm{~K}-36 \mathrm{ks}$ for Ti-Zr alloy and $723 \mathrm{~K}-36 \mathrm{ks}$ for Ti-Sn alloy.

\section{Mechanical Properties of Solution-treated and Aged Alloys}

Table 2 shows the room temperature strengths of $\mathrm{Ti}-\mathrm{Zr}$ and Ti-Sn alloys solution-treated and aged under optimized conditions compared to those of annealing. The $0.2 \%$ proof strength and tensile strength of both alloys increased after solution treatment and aging, but the elongation and reduction of area of the solution-treated and aged alloys were lower than those of annealed alloys. The strength and ductility of both alloys were higher than the ASTM values specified for Ti-6\%Al-4\%V ELI for surgical implantation $(\mathrm{F} 136-84)^{(22)}$.
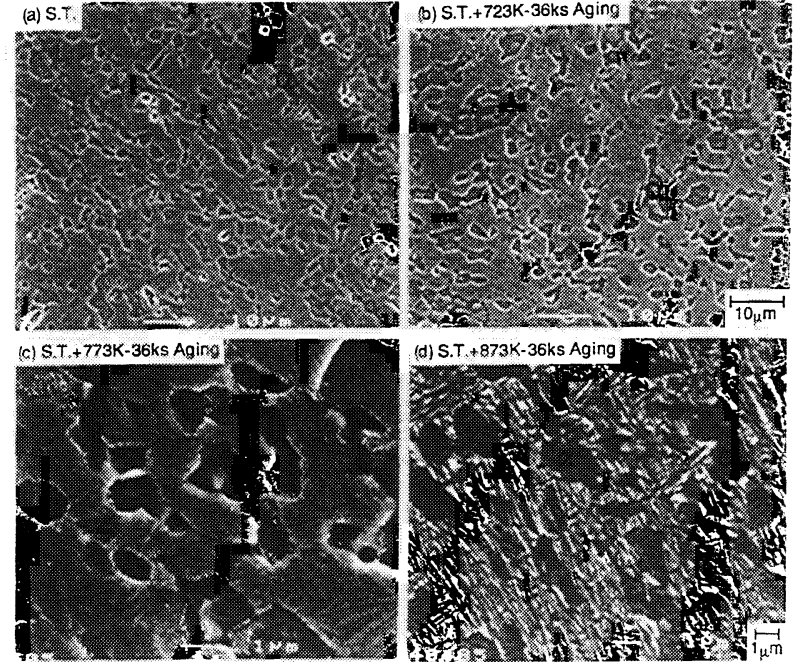

Fig.5 SEM micrographs of Ti- $15 \% \mathrm{Sn}-4 \% \mathrm{Nb}-2 \% \mathrm{Ta}-0.2 \% \mathrm{Pd}$ alloy.

(a):Solution treatment (S.T.), (b):S.T.t aging at $723 \mathrm{~K}$ for $36 \mathrm{ks}$

(c):S.T.+ aging at $773 \mathrm{~K}$ for $36 \mathrm{ks,} \mathrm{(d):} \mathrm{S.T.+} \mathrm{aging} \mathrm{at} 873 \mathrm{~K}$ for $36 \mathrm{ks.}$
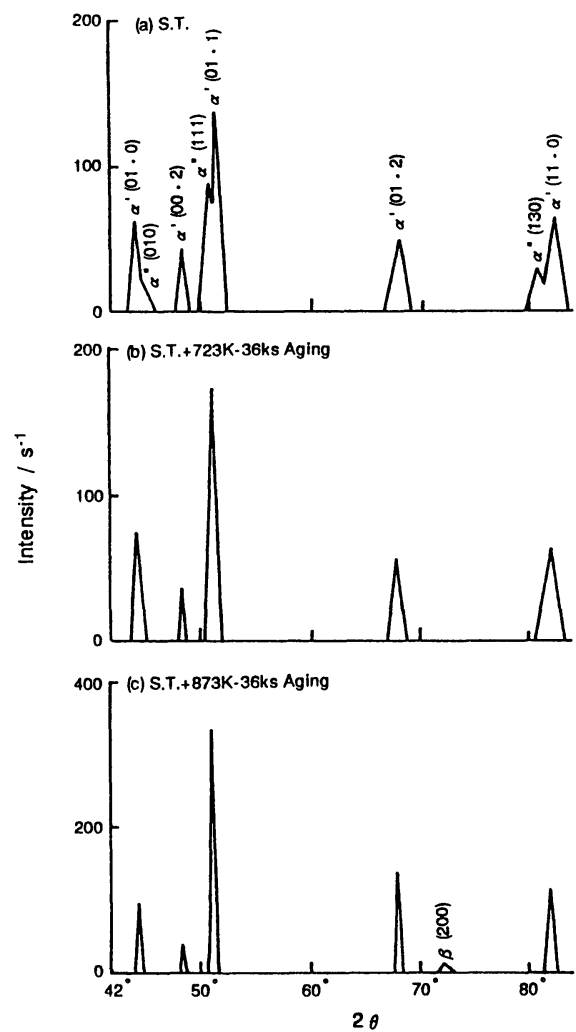

Fig.6 X-ray diffraction profiles of Ti-15\%Sn-4\%Nb-2\%Ta-0.2\%Pd.

(a): Solution treatment (S.T.), (b): S.T.+aging at $723 \mathrm{~K}$ for $36 \mathrm{ks,}$

(c): S.T.+ aging at $873 \mathrm{~K}$ for $36 \mathrm{ks}$.

When the new alloy is used as the stems of artificial hip joints, its Young's modulus should be as close to that of compact bone as possible because the greater the difference between the two values, the more the patient becomes vulnerable to the loosing of bone interface and bone fracture. While the Young's modulus of bone is as low as about $20 \mathrm{GPa}, \mathrm{Ti}-6 \% \mathrm{Al}-4 \% \mathrm{~V}$ ELI and the new $\mathrm{Ti}$ alloy for surgical implantation have nearly the same modulus of 100 $\mathrm{GPa}$ and $90 \sim 100 \mathrm{GPa}$, respectively, which is comparatively closest to the value of compact bone as compared to SUS316L (200 Gpa) and Co-Cr (200 $230 \mathrm{Gpa})$ alloys. 
Table 2 Comparison of mechanical properties of alloys annealed and aged after solution treatment with those of Ti-6\%Al-4\% ELI

\begin{tabular}{c|c|c|c|c|c}
\hline \hline \multirow{2}{*}{$\begin{array}{c}\text { Mechanical } \\
\text { properties }\end{array}$} & Alloys & Ti - 6\%Al - 4\%V ELI & \multicolumn{2}{|c|}{ Ti - 15\%Zr - 4\% - 0.2\%Pd } & \multicolumn{2}{c}{$\mathrm{Ti}-15 \% \mathrm{Sn}-4 \% \mathrm{Nb}-0.2 \% \mathrm{Ta}-0.2 \% \mathrm{Pd}$} \\
\cline { 2 - 6 } & 795 & Annealing & S.T. + Aging & Annealing & S.T. + Aging \\
\hline $\begin{array}{c}0.2 \% \text { Proof strength } \\
\boldsymbol{\sigma}_{0.2 \% \mathrm{Pd} / \mathrm{MPa}}\end{array}$ & 860 & 715 & 806 & 790 & 1020 \\
\hline $\begin{array}{c}\text { Tensile strength } \\
\sigma_{\text {UTS / MPa }}\end{array}$ & 10 & 28 & 919 & 860 & 1109 \\
\hline $\begin{array}{c}\text { Total elongation } \\
\%\end{array}$ & 25 & 67 & 72 & 21 & 10 \\
\hline $\begin{array}{c}\text { Reduction of area } \\
\%\end{array}$ & 100 & 94 & 99 & 64 & 39 \\
\hline $\begin{array}{c}\text { Young's modulus } \\
\text { E/GPa }\end{array}$ & & & & 103 \\
\hline
\end{tabular}

S.T. : Solution treatment

\section{TEM Micrographs of Solution-treated and Aged Alloys}

Microstructures of the test alloys were examined using a transmission electron microscope in order to clarify the reasons for the increase in their hardness and strength after solution treatment and aging. Figure 7 shows SEM and TEM micrographs of the alloys after annealing at $973 \mathrm{~K}$ for $7.2 \mathrm{ks}$. The white phase noted in the SEM micrographs is $\beta$ phase at $973 \mathrm{~K}$ which is transformed almost entirely to $\alpha$ phase during cooling, as is clear from the $\mathrm{X}$-ray diffraction profiles shown in Figure 8. The TEM micrographs in Figure 7(b) show the cell structure of $\alpha$ phase transformed from $\beta$ phase. The $\beta$ phase seen in the $\mathrm{X}$-ray diffraction profiles of Ti-Sn alloy envelops the $\alpha$ phase and appears black in the TEM micrographs as shown in Figure 7(e).
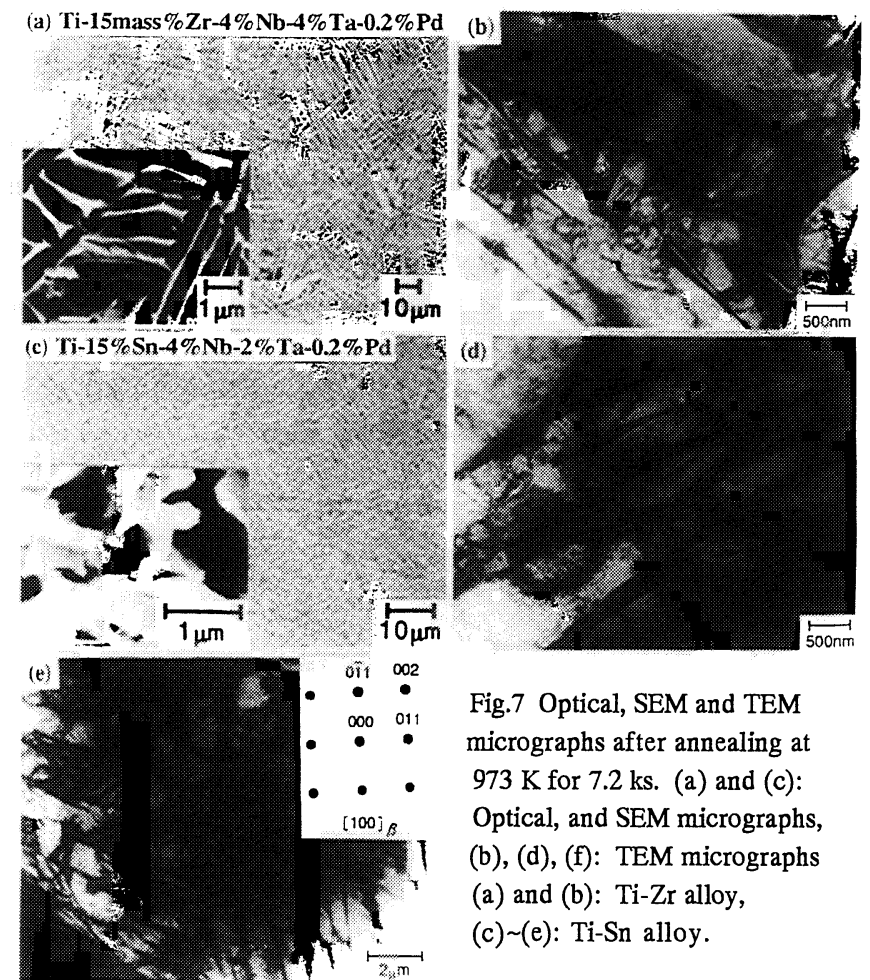

Fig.7 Optical, SEM and TEM micrographs after annealing at $973 \mathrm{~K}$ for $7.2 \mathrm{ks}$. (a) and (c): Optical, and SEM micrographs, (b), (d), (f): TEM micrographs (a) and (b): Ti-Zr alloy, (c) (e): Ti-Sn alloy.
Although the results are different from the chemical analysis shown in Table 1, quantitative analysis using EDX disclosed that $\beta$ phase (Sn: 10.7 mass $\%$, Nb: $14.7 \%$, Ta: $2.8 \%$ ) contained a little less $\mathrm{Sn}$ and a little more $\mathrm{Nb}$ and $\mathrm{Ta}$ than the $\alpha$ phase matrix (Sn: $12.8 \%, \mathrm{Nb}: 4.3 \%$, Ta: small amount). $\mathrm{Nb}$ and $\mathrm{Ta}$ are $\beta$ stabilizing elements while $\mathrm{Sn}$ is considered to be $\alpha$ stabilizing element.

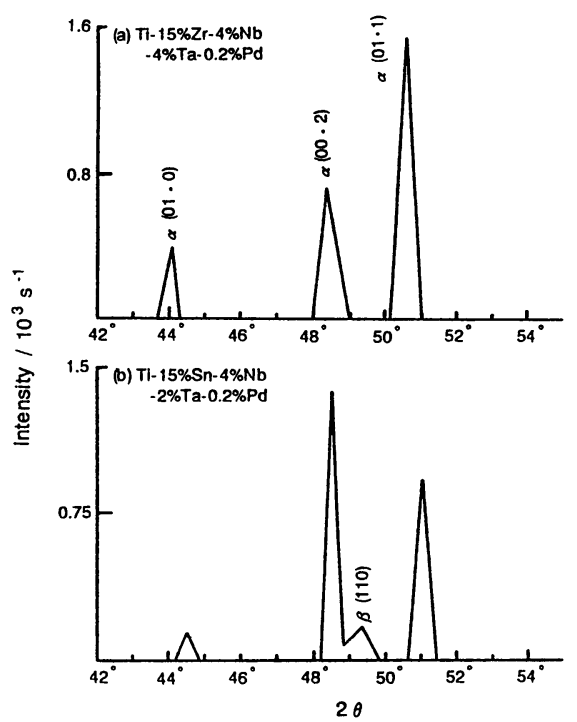

Fig.8 X-ray diffraction profiles after annealing at $973 \mathrm{~K}$ for $7.2 \mathrm{ks}$.

Figure 9 shows the TEM micrographs of Ti-Zr alloy aged after solution treatment. As seen in the figure, primary $\alpha$ and lath-like $\alpha^{\prime}$ martensite can be observed for the solution-treated alloy, while $\alpha$ phase precipitation at intersections of lath-like martensite and the growth of $\alpha$ phase with increasing aging time can be observed for the alloy aged at $673 \mathrm{~K}$ for $1.8 \mathrm{ks}$. It can also be seen that recrystallization and growth of $\alpha$ phase precipitates in the lath-like $\alpha^{\prime}$ martensitic matrix increases with increasing aging temperature. Figure 10 shows the TEM micrographs of Ti-Sn alloy. Although the martensite of the solution-treated alloy shows certain differences, fine $\alpha$ phase precipitates due to aging can be observed similar to those of Ti-Zr alloy. The concentration of alloying elements in the primary $\alpha$ phase and martensite after aging was examined using EDX, and the results are shown in Table 3. The concentration of alloying elements in the new $\alpha$ phase precipitation by aging nearly coincided with that in primary $\alpha$ phase after solution treatments. The concentration of $\beta$ phase stabilizing elements, namely, $\mathrm{Nb}$ and $\mathrm{Ta}$, tend to be higher in $\alpha^{\prime}$ martensite than in $\alpha$ phase. 


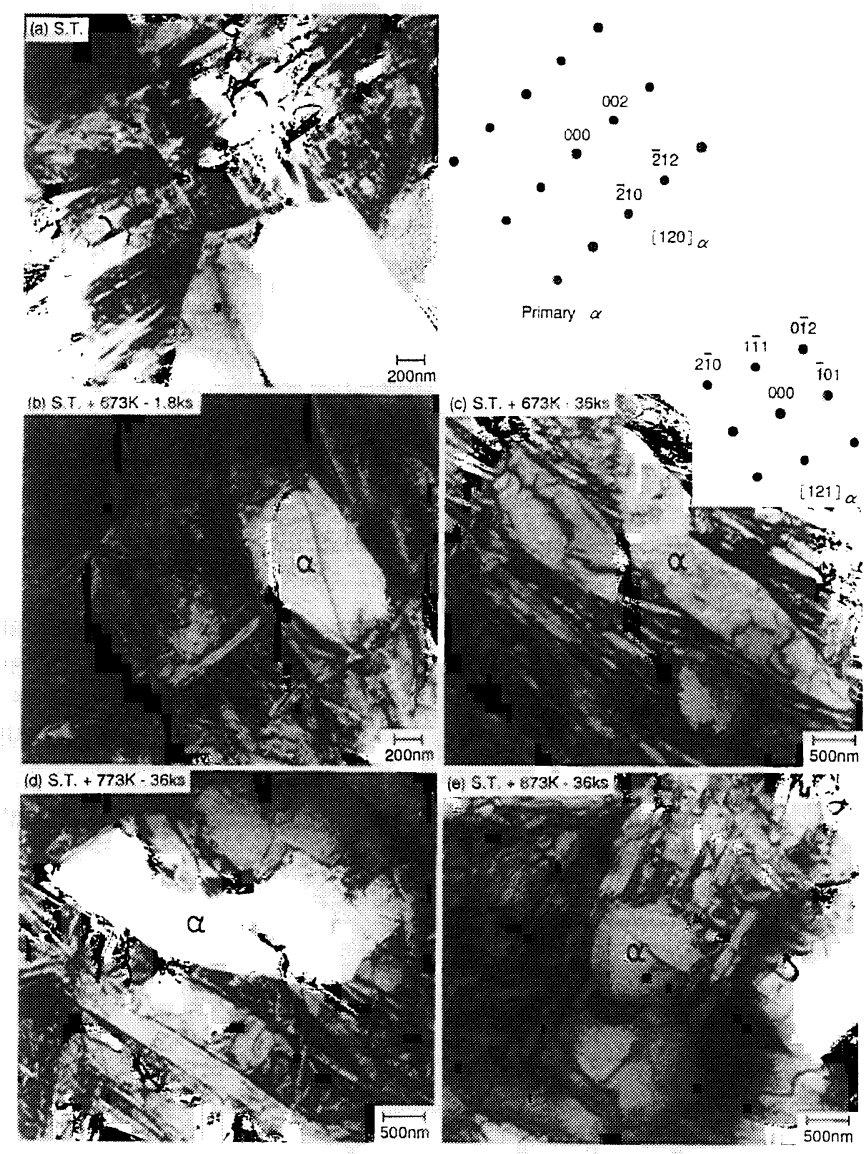

Fig.9 TEM micrographs of Ti-15\%Zr-4\% Nb-4\% Ta-0.2\%Pd alloy aged at $673 \sim 873 \mathrm{~K}$ for $1.8 \sim 36 \mathrm{ks}$ after solution treatment at $1038 \mathrm{~K}$ for $3.6 \mathrm{ks}$. (a): Solution treatment (S.T.), (b): S.T.+aging at $673 \mathrm{~K}$ for $1.8 \mathrm{ks}$, (c): S.T.+ aging at $673 \mathrm{~K}$ for $36 \mathrm{ks,} \mathrm{(d):} \mathrm{S.T.+aging} \mathrm{at} 773 \mathrm{~K}$ for $36 \mathrm{ks}$, (e): S.T.+ aging at $873 \mathrm{~K}$ for $36 \mathrm{ks}$.

Table 3 Comparison of concentration (mass\%) of alloying elements in primary $\alpha$ phase after solution treatment and $\alpha$ phase precipitated in aging.

\begin{tabular}{|c|c|c|c|c|c|c|c|}
\hline \multicolumn{4}{|c|}{ Ti- Zr } & \multicolumn{4}{|c|}{ Ti- Sn } \\
\hline \multirow{4}{*}{ S.T. } & & $\alpha$ & $\alpha^{\prime}$ & \multirow{4}{*}{ S.T. } & & $\alpha$ & $\alpha^{\prime}$ \\
\hline & $\mathrm{Zr}$ & 13.2 & 18.9 & & $\mathrm{Sn}$ & 13.6 & 11.7 \\
\hline & $\mathrm{Nb}$ & 2.5 & 5.8 & & $\mathrm{Nb}$ & 3.0 & 7.7 \\
\hline & $\mathrm{Ta}$ & 2.4 & 3.2 & & $\mathrm{Ta}$ & - & 1.5 \\
\hline \multirow{3}{*}{$\begin{array}{l}\text { S.T. }+ \\
673 \mathrm{~K}-1.8 \mathrm{ks}\end{array}$} & $\mathrm{Zr}$ & 13.9 & 17.6 & \multirow{3}{*}{$\begin{array}{l}\text { S.T. }+ \\
673 \mathrm{~K}-1.8 \mathrm{ks}\end{array}$} & $\mathrm{Sn}$ & 13.8 & 13.3 \\
\hline & $\mathrm{Nb}$ & 1.8 & 5.0 & & $\mathrm{Nb}$ & 3.3 & 6.4 \\
\hline & $\mathrm{Ta}$ & 2.2 & 2.7 & & $\mathrm{Ta}$ & - & 1.1 \\
\hline \multirow{3}{*}{$\begin{array}{l}\text { S.T. }+ \\
873 K-36 k s\end{array}$} & $\mathrm{Zr}$ & 17.4 & 19.7 & \multirow{3}{*}{$\begin{array}{l}\text { S.T. }+ \\
873 K-36 k s\end{array}$} & Sn & 12.7 & 13.2 \\
\hline & $\mathrm{Nb}$ & 2.6 & 6.4 & & $\mathrm{Nb}$ & 2.8 & 6.6 \\
\hline & $\mathrm{Ta}$ & 2.5 & 4.6 & & $\mathrm{Ta}$ & 0.8 & 1.1 \\
\hline
\end{tabular}

As described above, it was revealed that when the alloy is solution-treated immediately below the $\beta$ transition temperature and aged at $673 \sim 723 \mathrm{~K}$ for $36 \mathrm{ks}, \alpha$ phase precipitates from the lath intersections of the fine $\alpha^{\prime}$ martensite produced by solution treating, and that the alloy strength can be increased to maximum extent when the $\alpha$ phase precipitates are finely and uniformly distributed.

\section{Corrosion Fatigue Strength}

When the current density measured by anodic polarization testing in a physiological saline solutions becomes too low, the corrosion resistance of implants in the living body must be excellent ${ }^{(3)(20)}$

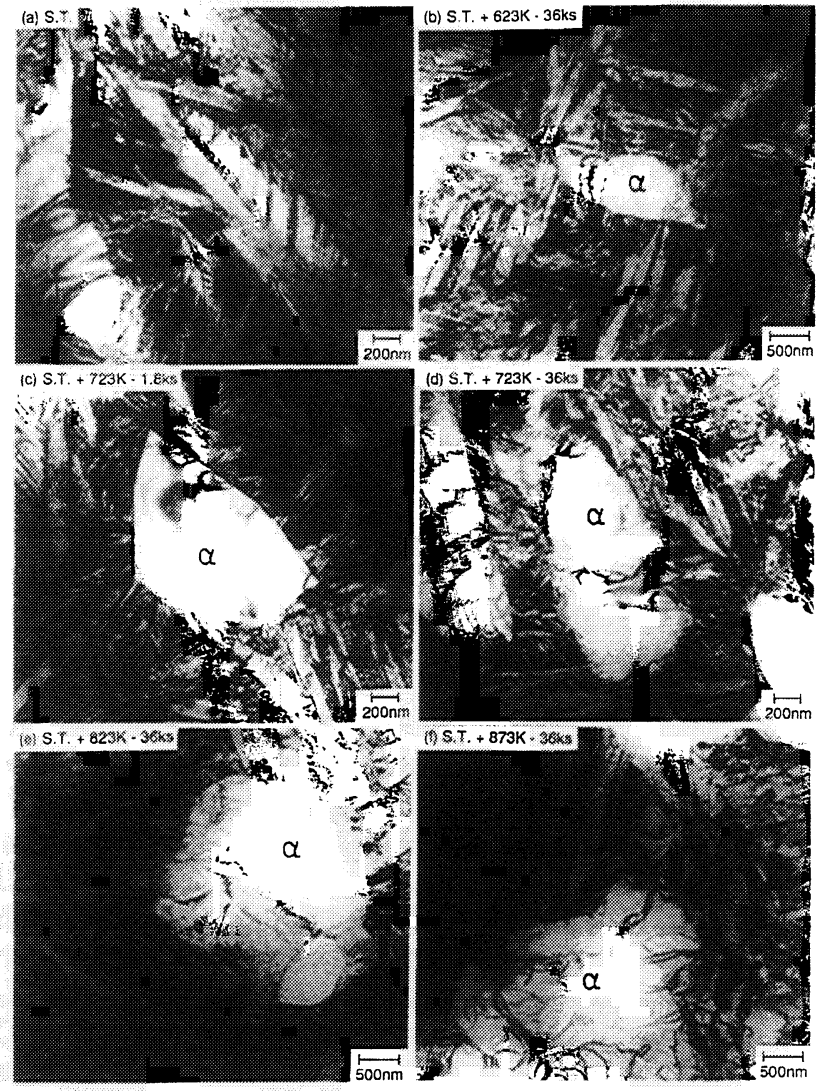

Fig.10 TEM micrographs of Ti-15\%Sn-4\%Nb-2\% Ta-0.2\%Pd alloy aged at $623 \sim 873 \mathrm{~K}$ for $1.8 \sim 36 \mathrm{ks}$ after solution treatment at $1098 \mathrm{~K}$ for 3.6 ks. (a): Solution treatment(S.T.), (b): S.T.+aging at $623 \mathrm{~K}$ for $36 \mathrm{ks}$, (c): S.T.+ aging at $723 \mathrm{~K}$ for $1.8 \mathrm{ks,} \mathrm{(d):} \mathrm{S.T.+aging} \mathrm{at} 723 \mathrm{~K}$ for 36 ks, (e): S.T. + aging at $823 \mathrm{~K}$ for $36 \mathrm{ks}$, (f): S.T.+ aging at $873 \mathrm{~K}$ for $36 \mathrm{ks}$.

Figure 11 shows anodic polarization curves measured in $450 \mathrm{ml}$ Eagle's MEM+50 $\mathrm{ml}$ fetal bovine serum solution deaerated with high-purity $\mathrm{N}_{2}$ gas bubbling at $310 \mathrm{~K}$ (37 ${ }^{\circ} \mathrm{C}$ ). The current density in the electric potential region of $1 \mathrm{~V}$ or more increases as the electric potential increases and increases rapidly in the potential region of $2 \mathrm{~V}$ or more. Current density at higher voltage region more than 2 volts tend to be higher in the following relation ; Ti-6\%Al-4\% V ELI $>$ Pure Ti grade $2>\mathrm{Ti}-15 \% \mathrm{Sn}-4 \% \mathrm{Nb}-2 \% \mathrm{Ta}-0.2 \% \mathrm{Pd}>$ Ti-15\%Zr-4\%Nb-4\%Ta-0.2\% Pd alloy ${ }^{(17)}$.

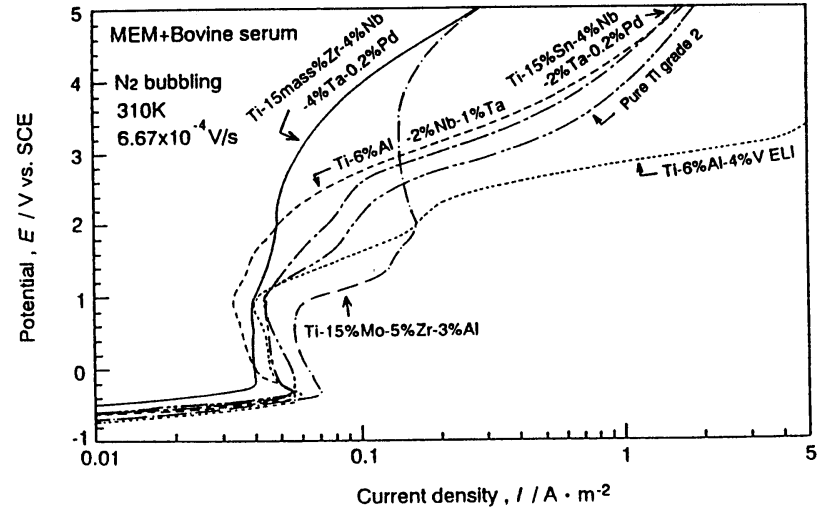

Fig.11 Comparison of the anodic polarization curves for medical implants in a deaerated Eagle's MEM + bovine serum at $310 \mathrm{~K}$. 
Figures 12 shows the S-N curves obtained from the corrosion fatigue test conducted in the physiological saline solution. Comparison of Ti-15\%Sn-4\%Nb-2\%Ta-0.2\%Pd with Ti-15\%Zr-4\%Nb-4\% Ta-0.2\%Pd indicates that Ti-Sn alloys having a higher room temperature strength tend to have a larger number of cycles to failure in both case of annealing and solution treatment+aging. The fatigue strength at $10^{8}$ cycles in solution-treated+aged Ti-15\%Zr-4 $\% \mathrm{Nb}-4 \% \mathrm{Ta}-0.2 \% \mathrm{Pd}$ and $\mathrm{Ti}-15 \% \mathrm{Sn}-4 \% \mathrm{Nb}-4 \% \mathrm{Ta}-0.2 \% \mathrm{Pd}$ alloys were about $650 \mathrm{MPa}$ and $800 \mathrm{MPa}$ respectively, and they were about $20 \sim 30 \%$ higher than those of the annealed alloys.

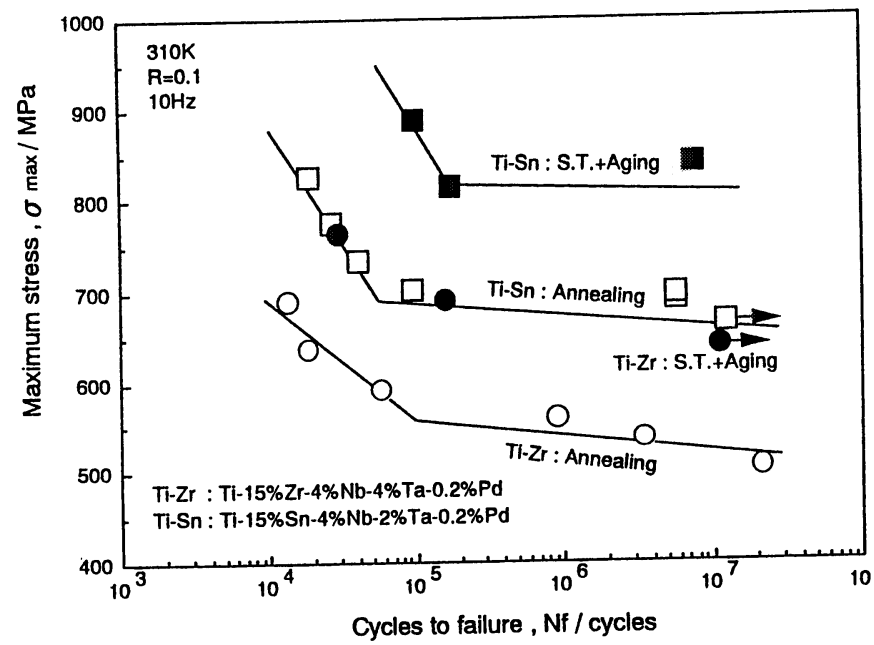

Fig.12 Effect of heat treatment on the S-N curves obtained by corrosion fatigue test in a physiological saline solution at $310 \mathrm{~K}$.

\section{Conclusion}

For the purpose of increasing the strength of $\mathrm{Ti}$ alloys for surgical implantation, they were solution-treated in the vicinity of $\beta$ transition temperature and aged in the low temperature region, and the following results were obtained.

(1) Vickers hardness of both Ti-Zr and Ti-Sn alloys increases with increasing solution treating temperatures, and remains almost constant at temperatures higher than the $\beta$ transition temperature. The alloy has a two-phase $(\alpha+\beta)$ microstructure when the solution treating temperature is low, but the $\beta$ phase grows with increasing solution treating temperatures, and a fine primary $\alpha$ phase precipitates in the $\beta$ matrix immediately below the $\beta$ transition temperature. Optimized solution treatment conditions for securing $15 \sim 20 \%$ volume fraction of primary $\alpha$ phase are $1038 \mathrm{~K}-3.6 \mathrm{ks}$ for $\mathrm{Ti}-\mathrm{Zr}$ alloy and $1098 \mathrm{~K}-3.6 \mathrm{ks}$ for Ti-Sn alloy.

(2) By aging $\mathrm{Ti}-\mathrm{Zr}$ alloy at $673 \mathrm{~K}$ for $36 \mathrm{ks}$ and Ti-Sn alloy at $723 \mathrm{~K}$ for $36 \mathrm{ks}$ after solution treatment, their strength can be increased while maintaining their ductility at a level equivalent to or higher than the ASTM value specified for Ti-6\% Al-4\%V ELI for surgical implantation. As far as the strength augmentation mechanism is concerned, it has been found that $\alpha$ phase precipitates from the lath intersections of fine $\alpha^{\prime}$ martensite produced by solution treatment, and that the alloy strength is increased when the $\alpha$ phase precipitates are finely distributed.
(3) Comparison of corrosion fatigue strength of Ti-15\%Sn-4\%Nb-2\%Ta-0.2\%Pd and Ti-15\%Zr-4\%Nb-4\% $\mathrm{Ta}-0.2 \% \mathrm{Pd}$ alloy indicates that $\mathrm{Ti}-\mathrm{Sn}$ alloy having a higher room temperature strength tend to have a larger number of cycles to failure in both annealing and solution treatment+aging. The fatigue strengths at $10^{8}$ cycles in solution-treated and aged $\mathrm{Ti}-\mathrm{Zr}$ and $\mathrm{Ti}-\mathrm{Sn}$ alloys were about $650 \mathrm{MPa}$ and $800 \mathrm{MPa}$ respectively. These values are about 20 30\% higher than those of annealed alloys.

\section{Acknowledgment}

The authors are pleased to acknowledge the experimental support of Dr. Yoshikuni Kawabe, Director, and Mr. Junji Takahashi of the Mechanical Properties Division, National Research Institute of Metals, for casting by plasma electron beam melting.

\section{REFERENCES}

(1) S. G. Steinemann: Evaluation of Biomaterials, Ed. by G. D. Winter, J. L . Leray, K. de Goot, John Wiley \& Sons Ltd. , (1980), 1.

(2) Y. Okazaki, Y. Ito, T. Tateishi and A. Ito: J. Japan Inst. Metals, 59 (1995), 108.

(3) Y. Okazaki, Y. Ito, A. Ito and T. Tateishi: Metallurgy And Technology of Practical Titanium Alloys, Ed. by S. Fujishiro, D. Eylon and T.Kishi, The Minerals, Metals \& Materials Society, (1994), 313.

(4) Y. Okazaki, K. Kyo, Y. Ito and T. Tateishi : J. Japan Inst. Metals, 59 (1995), 1061.

(5) ASTM Committee F04/ Titanium Development Association Symposium on Medical Applications of Titanium and Its Alloys : The Materials and Biological Issues, November 14-18, (1994), Phoenix, Arizona.

(6) J. P. Landsberg, B. McDonald and F. Watt: Nature (London), 360 (1992), 65.

(7) S. Yumoto, H. Ohashi, H. Nagai, S. Kakimi, Y. Ogawa, Y. Iwata and $\mathrm{K}$. Ishii : Intemational Journal of PIXE, World Scientific Publishing Company, 2 (1992), 493.

(8) G. Farrar, P. Altmann, S. Welch, O. Wychrij, B. Ghose, L. Lejeune, J. Corbett, V. Prasher and J. Blair : Lancet, 335 (1990), 747.

(9) K. A. Winship: Adverse Drug React. Toxicol. Rev., 11 (1992), 123.

(10) R. S. Jope and G. V. W. Johnson: Aluminium in Biology and Medicine, Wiley, Chichester, Ciba Foundation Symposium 169 (1992), 254.

(11) D.R. Crapper McLachlan, W J. Lukiw and T. P. A. Kruck : Environ. Geochm. Health, 12(1/2) (1990), 103.

(12) W. Kaim and B. Schwederski : Bioinorganic Chemistry: Inorganic Elements in the Chemistry of Life, John Wiley \& Sons Ltd, (1994), 330.

(13) R.Michel : CRC Critical Reviews in Biocompatibility, 3(1987), 235.

(14) H. J. Agins, N. W. Alock,. M. Bansal, E. A. Salvati, P. D. Wilson, P. M. Pellicci Jr. and P. G. Bullonugh: Journal of Bone and Joint Surgery, 70-A(1988), 347.

(15) H. Kawahara: Bulletin of the Japan Institute of Metals, 31 (1992), 1033.

(16) M. R. Krigman and A. P. Silverman: Neuro Toxicology, 5 (1984), 129.

(17) K. A. Winship: Adverse Drug React. Ac. Pois. Rev., 1 (1988),19.

(18) S.G. Schafer, and U. Femfert: Regulatory Toxicology and Pharmacology, 4 (1984), 57.

(19) Y. Okazaki, Y. Ito, A. Ito and T. Tateishi: Materials Transactions, JM, 34 (1993), 1217.

(20) Y. Okazaki, A. Ito, T. Tateishi and Y. Ito : Materials Transactions, JM, 35 (1994), 58.

(21) Y. Okazaki, M. Ohota, Y. Ito and T. Tateishi: J. Japan Inst. Metals, 59 (1995), 229.

(22) ASTM F136-84: Annual Book of ASTM Standards, ASTM, 13.01(1991), 38. 